\title{
Antibiotic and cytotoxic peptides
}

\author{
Norbert Sewald
}

\section{Editorial \\ Address: \\ Bielefeld University, Department of Chemistry, Organic and \\ Bioorganic Chemistry, Universitätsstr. 25, 33615 Bielefeld, Germany \\ Email: \\ Norbert Sewald - norbert.sewald@uni-bielefeld.de \\ Keywords: \\ antibiotic; cytotoxic; peptides}

Open Access

Beilstein J. Org. Chem. 2012, 8, 1144-1145

doi:10.3762/bjoc.8.127

Received: 05 July 2012

Accepted: 06 July 2012

Published: 24 July 2012

This article is part of the Thematic Series "Antibiotic and cytotoxic peptides".

Guest Editor: N. Sewald

(C) 2012 Sewald; licensee Beilstein-Institut.

License and terms: see end of document.
Through evolution, nature has provided practically all organisms with secondary metabolites: chemical compounds that provide the producing species with specific protective mechanisms or other advantages. Among these, there are, e.g., peptides that display antibiotic/antimicrobial activity. These have been isolated from plants, invertebrates, vertebrates, and humans, but also from microorganisms. Some antibiotic peptides are an essential part of innate immunity, which has evolved in most organisms to combat microbial challenge. In addition, antimicrobial peptides sometimes also display cytotoxicity against mammalian cells.

There are several good reasons for a Thematic Series in the Beilstein Journal of Organic Chemistry on "Antibiotic and cytotoxic peptides": The fight against bacterial infections is in a critical phase. The excessive application of antibiotics in human therapy, and also in livestock breeding, leads to the rapid development of highly virulent bacterial strains resistant to the conventionally applied antibiotics. Consequently, the search for new antibiotically active compounds is of premier importance. On the other hand, highly cytotoxic peptides and peptide analogues, such as monomethyl auristatin E, are used as the "warhead" in antibody-drug conjugates for tumor therapy, as approved recently by the FDA [1].
It is a privilege of synthetic chemists to be able to modify natural products by total synthesis. Many naturally occurring compounds are highly complex, and their efficient total synthesis often is out of reach. However, in frequent cases structural simplifications have proven amenable, and the resulting compounds have sometimes been shown to retain biological activity. The challenge of discovering new antibiotically active or cytotoxic compounds persists. Moreover, peptides have experienced a renaissance during recent years with respect to their application in Medicinal Chemistry [2].

This Thematic Series on "Antibiotic and cytotoxic peptides" presents contributions from synthetic chemists active in the fields of peptides, peptidomimetics, drug design, and method development, in order to promote the research area further and to disseminate the interdisciplinary research efforts to a broader audience.

\section{Norbert Sewald}

Bielefeld, July 2012 


\section{References}

1. Sammet, B.; Steinkühler, C.; Sewald, N. Pharm. Pat. Analyst 2012, 1, 65-73. doi:10.4155/ppa.12.4

2. Hoffmann, T.; Metternich, R. Angew. Chem., in press. doi:10.1002/ange.201201677

\section{License and Terms}

This is an Open Access article under the terms of the Creative Commons Attribution License

(http://creativecommons.org/licenses/by/2.0), which permits unrestricted use, distribution, and reproduction in any medium, provided the original work is properly cited.

The license is subject to the Beilstein Journal of Organic Chemistry terms and conditions:

(http://www.beilstein-journals.org/bjoc)

The definitive version of this article is the electronic one which can be found at: doi:10.3762/bjoc. 8.127 